inOedia $\quad \begin{aligned} & \text { InMedia } \\ & \text { The French Journal of Media Studies }\end{aligned}$

3 | 2013

Cinema and Marketing

\title{
The Multiple Facets of Enter the Dragon (Robert Clouse, 1973)
}

Pierre-François Peirano

\section{(2) OpenEdition \\ Journals}

Electronic version

URL: http://journals.openedition.org/inmedia/613

ISSN: 2259-4728

Publisher

Center for Research on the English-Speaking World (CREW)

\section{Electronic reference}

Pierre-François Peirano, «The Multiple Facets of Enter the Dragon (Robert Clouse, 1973) », InMedia

[Online], 3 | 2013, Online since 21 April 2013, connection on 07 September 2020. URL : http://

journals.openedition.org/inmedia/613

This text was automatically generated on 7 September 2020 .

(c) InMedia 


\title{
The Multiple Facets of Enter the Dragon (Robert Clouse, 1973)
}

\author{
Pierre-François Peirano
}

1 In the field of American foreign policy, the early 1970s witnessed warmer relations between the United States and the Chinese-speaking world, as showed the official visit to Beijing by President Nixon, in February 1972. As if to provide a direct answer to this key political event-the first time a President of the United States had paid an official visit to China-, the cinema industry got in tune and, the following year, Enter the Dragon was released, the first ever co-production between a Hollywood studio, Warner Bros., and a Hong Kong production company, that of Raymond Chow and Bruce Lee-even though, of course, Hong Kong was not part of the People's Republic of China at the time. More than the resurgence of the dream of establishing long-term relationships with Cathay, which was shared by numerous Founding Fathers in the period of the Early Republic, the movie was first intended to launch the career of actor and martial arts champion Bruce Lee in Hollywood. Even though his fame was already extending far beyond the borders of Hong Kong-with movies like Big Boss (Wei Lo, 1971), Fist of Fury (Wei Lo, 1972) and Return of the Dragon (Bruce Lee, 1972), the first ever Hong Kong film shot in Europe-, he had only made brief appearances in American movies or series.

2 The film that was supposed to promote Lee on the American market-even though he was a United States citizen-had to work according to a precise formula. It had to stick to the previous kung-fu movies that had made him famous, while introducing elements that were susceptible of attracting Asian, American, as well as European audiences-the eventual success of the movie was not fully predictable, though.

3 This was why Enter the Dragon followed the framework of a kung-fu movie, while including elements belonging to adventure or espionage ones, and was promoted differently according to the countries or areas in which it was released, so as to appeal to a wide variety of audiences. To do so, the characters and the plot were portrayed under a different light, which was made easier by the various elements of the work, a blend of numerous genres. 
4 The film met considerable success, as Enter the Dragon, with a 25-million-dollar operating profit in the United States, was one of the most successful movies of 1973. A close analysis of its promotion shows that it used the identity, or the stereotypes, associated to a particular area to make the work as attractive as possible-according to the targeted audience. This article is divided into three parts. First, the emphasis is laid on the various elements of the movie that enabled its promotion and that the spectators could also associate to other contemporary movies-the first condition of success. Then, the workings of the promotion is analyzed and illustrated by a study of the original posters and trailers, which account for revealing differences according to the targeted markets. Lastly, the underlying political message, another corollary of a successful promotion-particularly in the United States-is highlighted.

\section{At the Crossroads of Various Genres}

5 First, however, a short overview of the plot, partly the work of Bruce Lee himself, remains necessary. Lee (Bruce Lee), a Shaolin martial arts specialist, is asked by Braithwaite (Geoffrey Weeks), a member of the British secret service, to take part in a tournament organized by the mysterious Mr. Han (Shih Kien) on his island, off the Hong Kong territory. Indeed, the British have long suspected Han of being the leader of a prostitution and drug-trafficking ring, but all the previous attempts to infiltrate his organization have failed. Lee accepts to carry out this task and, almost simultaneously, learns that Han was himself a former disciple of the Shaolin Temple, but was expelled after contravening its rules, and that Han's bodyguard, O'Hara (Robert Wall), was involved in the suicide of Lee's elder sister. The desire for revenge thus urges him further to go to Han's island.

6 Among others, two martial arts specialists, Roper (John Saxon) and Williams (Jim Kelly), are also taking part in this tournament. While the former has to pay off a debt to the Mob, the latter had to flee the United States after an altercation with two prejudiced policemen. The three of them will respectively play a part in dismantling Han's organization and this summary already shows that the movie can be linked to the "high concept" theory, which, in the United States, applies to movies most likely to bring in profits. Numerous factors come into play: first, the "international" character of the work, not forgetting the possibility of summing up the plot in twenty words or so. ${ }^{1}$ In the case of Enter the Dragon, it is possible to write, "Three men are going to try to dismantle, during a martial arts tournament, Han's mysterious organization" (16 words). However, one feature of the "high concept" does not seem to apply to Enter the Dragon: according to this theory, a film falling into this category has to belong to a specific genre. For the film directed by Robert Clouse, however, a blending of various genres was essential to its promotion and its success.

7 In the first place, Enter the Dragon can be considered as a kung-fu movie properly speaking and several of its elements were susceptible of attracting an Asian audience, who had a better knowledge of the character of Bruce Lee and his previous films. For this type of audience, continuity was thus privileged and the previous codes respected. In the Hong Kong trailer, fight scenes are overwhelmingly present and the theme of revenge, one of the main workings of previous films such as Fist of Fury-in which Lee avenged the death of his former instructor-, is also to be found in Enter the Dragon. One could even draw a parallel with $14^{\text {th }}$ - and $16^{\text {th }}$-century classical Chinese novels such as 
Water Margin (Shui-hu-zhuan) or The Journey to the West (Xi youji), that have remained quite popular and in which characters linked by a common past meet again, haphazardly, without being previously acquainted. In the case of Enter the Dragon, Han has offended the Shaolin Temple and O'Hara, his bodyguard, is indirectly responsible for the suicide of Lee's elder sister. In his introduction to Water Margin, French sinologist Jacques Dars wrote:

One could claim that the book is composed of several stories rather than one story, [...] as the reader is led through twists and turns, meanders and digressions. However, he follows the way without any reluctance, as the carefully-crafted and interwoven plots follow one another and captivate him. He has the opportunity to make better acquaintance with strongly individualistic, often complex characters, confronted to unexpected situations. Lastly, through the various protagonists, the Chinese society of the time, in its admirable and picturesque variety, is gradually revealed. ${ }^{2}$

In Enter the Dragon, of course, one does not come across such high standards, but similar workings are to be found-even though they do not cover the span of a classical noveland variety, also used to commercial purposes, still characterizes the work.

Indeed, this movie can be defined as the crucible of various genres and introducing other elements within the kung-fu movie formula could catch the attention of a "Western" audience-both in America and Europe-, who would recognize features borrowed from contemporary films and television series. First, those devoted to martial arts were already popular in the United States, as the broadcasting of the television series Kung Fu on ABC between 1972 and 1975 showed. In The Cinema of Hong Kong: History, Arts, Identity, first published in 2000, David Desser and Poshek Fu went as far as dubbing this trend "the kung-fu craze." ${ }^{3}$ Such a topic meant exoticism for the American audience and, in the trailer itself, the popularization of the Shaolin thought pattern, which pervades the movie, was already at work through the famous sentence professed by Lee to one of his disciples, "It is like a finger pointing away to the moon. Don't concentrate on the finger or you will miss all that heavenly glory." ${ }^{4}$ The references to natural elements and heavenly bodies had been, for a long time, associated to the Far East.

More importantly, the influence of other genres and other contemporary movies may be spotted at various levels. First, the character of Williams, an African American, is a direct reference to the trend known as "Blaxploitation"-various movies released in the early 1970s in an attempt to popularize and redeem the image of the African American community within the United States. ${ }^{5}$ His Afro hairstyle further accounts for this influence and gives strength to the "baroque" character of the movie, much like the presence of Roper, a White man. ${ }^{6}$ Seeing characters belonging to those ethnic groups practice martial arts and take part in a tournament in the company of Asians may, at first sight, seem as surprising as the arrival of cowboys at the court of Mexican Emperor Maximilian in the Western movie Vera Cruz (1954), by Robert Aldrich. In view of those trailers, the spectator would probably have thought this was a "hybrid" kungfu movie, in which the various characters came from various ethnic groups and different backgrounds. This feature is much more emphasized in the American trailer than in the Hong Kong one.

11 It now appears indispensable to mention the multiple references to the James Bond franchise. Actually, 007 had already made a trip to the Far East six years before in You Only Live Twice (Lewis Gilbert, 1967) and the latest-at the time-movie in the series, Live 
and Let Die (Guy Hamilton), also dealing with drug-trafficking, was to be released at about the same period, in 1973. In the light of this, the hypothesis that Warner Bros. wished to provide a direct reply to MGM and United Artists could be raised. At the beginning of Enter the Dragon, Braithwaite, a member of the British secret service-and a representative of the British Crown-has a conversation with Lee and assigns him to go to Han's island and find out whether the latter really indulges in illegal practices. Lee thus becomes a kind of secret agent, as Bernard Benoliel wrote, "Bruce Lee, who has become a secret agent, thus listens to his interlocutor's lecture and takes on, without any effort, some of 007's attributes as well as the codes of this large symbolic and economic machine." ${ }^{\prime}$ This feature of Enter the Dragon will be further analyzed in the following lines as, in his work, Benoliel just states a few facts before laying the emphasis on the aesthetics of the movie, as well as Bruce Lee's body language and presence on the screen. Han, who lives secluded on his island protected like a fortress, thus undeniably reminds one of Doctor No, even when seeing the trailer, as Braithwaite can be heard saying, "[Han] lives like a king on that island- totally self-sufficient."

More generally, many elements belonging to serial movies or comic books-references to Doctor Fu Manchu, for instance-are to be found in the movie as well. Let us take, as a revealing example, a plate from Cigars of the Pharaoh, the fourth Tintin comic book by Hergé, taken from the black and white album published in 1934. While Tintin is walking in underground corridors, an iron door suddenly shuts down behind him and he then faces cobras. Those elements are used in Enter the Dragon, when Lee investigates the underground base of the island, and the shot of the iron door being shut is inserted in the trailer. There does not seem to be, of course, a direct link between Hergé's plate and Enter the Dragon, but those elements send one back to the general codes of "serial" comic books or movies. Even at this stage, when the spectator had not seen the whole film yet, he/she could anticipate that the movie would feature mysterious characters, secret passages and traps, taking up the usual workings of those kinds of adventures.

Lastly, for a public more likely to appreciate classic movies, the climactic fight between Han and Lee in a room full of mirrors shared similarities with The Lady from Shanghai (Orson Welles, 1947), in which the final scene also unfolded in a similar place. All those elements taken together combined to make Enter the Dragon a movie likely to appeal to a wide audience, in Asia as well as in America or Europe. Lalo Schifrin's soundtrack, blending Far Eastern tones and rhythms recalling his previous compositions for the television series Mission: Impossible or the movie Dirty Harry (Don Siegel, 1971), also conveyed such a message. The critical reviews of the time also stressed this blending of genres, most of them claiming that the film was "halfway between Doctor No and $\mathrm{Fu}$ Manchu." 10

\section{The Various Posters and Trailers}

The various elements that have just been mentioned were highlighted in the various trailers and posters-which, at the time, constituted the most appropriate means of promoting the movie. But, according to the area-and to the targeted audience-, different features were respectively emphasized. It has to be stated, at first, that the political borders became quite porous and the territory of Hong Kong remained associated to the Far East at large, as part of a continuous interplay with Western references. For the main purpose in the film's marketing, given its hybrid character, 
was to promote it on various markets and make it as attractive as possible-stressing both its "international" character and its links with the identity of each targeted area.

On each continent, however, Enter the Dragon was boasted as a milestone, even a world première. In the American trailer, the voice-over said that it was "the first martial arts film produced by a major Hollywood studio." In the Hong Kong one, by contrast, it was promoted as "the first international film starring a leading Chinese actor" and the fight scenes were overwhelmingly present, as if to meet the expectations of the Asian audience and to imply that it was now possible to promote a kung-fu movie in the Western world.

Bruce Lee-a United States citizen of Chinese origin-and the character he plays on screen are thus used differently and his ethnic origin is highlighted for the Hong Kong market. However, the way the main characters are presented-not only Lee, but also Williams and Roper-in the trailers and the posters also reveals the inner workings of the film's marketing. In the American trailer, the three characters appear in succession-first Roper, then Williams, then Lee-and are then called "the deathly three." ${ }^{11}$ Each of them thus seems to play an equivalent role in the plot, probably because the various types of American spectators could identify to such and such character.

The American poster also reflects this trend, ${ }^{12}$ as the three characters are represented on top of it, along with actress Ahna Capri, who plays Han's lady friend, while Han is represented at the bottom. Her presence is much revealing: although she is far from being a main character, she is represented as one, probably to link Enter the Dragon with the James Bond franchise and make the "environment" of a kung-fu movie more familiar to the Western spectator. In the Hong Kong poster ${ }^{13}$ on the contrary, Bruce Lee really steals the show: he is represented three times instead of one, fighting, while Roper, Williams and Han only feature at the bottom. A similar choice is made in the Hong Kong trailer, which opens with Lee showing his skills in handling nunchaku, followed by a fight scene. ${ }^{14}$ For this audience, the actor and the character he plays must remain the center of attention, in continuity with previous movies. In this way, aesthetics also comes into play and the painstaking arrangement of the various fight scenes probably constituted another kind of appeal to the spectator. Even today, Lee's famous "crescent kick" in the climax fight with Han remains one of the bestremembered scenes in the movie and online videos are even exclusively devoted to it. ${ }^{15}$ However, this issue has already been studied in various other books, ${ }^{16}$ which is why the emphasis is laid on marketing itself.

18 Identity thus constitutes one of the main workings in the film's marketing. In Hong Kong, Lee is presented as a "Chinese"-notwithstanding the ambiguities this statement can lead to-and as the main character, while Roper and Williams are portrayed as playing second fiddle to Lee. In the trailer, the former appear in succession, before the Asian actors, who are totally neglected in the American trailer. On this market, the casting of Bruce Lee in the movie remains an exotic and attractive element, as he is described as a "martial arts champion" and as an "international star." Nevertheless, he remains a character among others, even a mere agent entrusted with an assignment. Indeed, the character of Braithwaite also appears in the trailer, giving instructions to Lee and answering one of his questions. More than a reminiscence of M, the MI6 chief in the Bond franchise, Braithwaite can also remind a Western spectator of British supervision in Hong Kong. It would also be useful to state that drug-trafficking could, 
more or less unconsciously, be associated to the colony of Hong Kong and its foundation, as the opium trade had played a key role in it, back in the mid- $19^{\text {th }}$ century. Braithwaite, as brief as his appearances may be, recalls this past and those commonplaces, while a further parallel is drawn with the Bond films in the American and European trailers. The posters destined to this area also convey a similar message: the same block capitals as in You Only Live Twice, the same arrangement as in Live and Let Die, released a month earlier. The main characters occupy the top of the poster, while the most spectacular scenes are represented at the bottom. The example of the French translation of the title sheds further light: Opération Dragon is a direct reference to Opération Tonnerre, the French translation for Thunderball, the 1965 James Bond movie directed by Terence Young. Lastly, Lalo Schifrin's soundtrack remains ever-present in each trailer. Borrowing key elements-or stereotypes-from various genres may lead one to assume that the screenplay of Enter the Dragon was underpinned by "textual poaching," 17 but it should be acknowledged that, at the same time, a kung-fu movie had greater chances of success if a large part of the audience could recognize elements from more familiar films or franchises. In this respect, the poster is just a detail and the trailers are much more revealing.

\section{Enter the Dragon and the American Social and Political Context}

While martial arts and entertainment are overwhelmingly emphasized in the Hong Kong trailer, the main characters and the key moments in the plot are introduced in the American one. Already, Han's island is described as a mysterious place, where the protagonists will be in a tight game, "Roper, Williams and Lee penetrate the secret chambers of an evil island empire," says the voice-over. ${ }^{18}$ The underlying message, which goes beyond the wish to expand on the Hong Kong market, is given more strength, as the American trailer also conveys a political message. Han is already portrayed as the villain and, interesting detail, always wears a shirt with a Mao collar. Furthermore, he wishes to recruit people who can help him develop his illegal practices in the United States-hence the proposal he makes to Roper, which is inserted in the trailer, "I'm hoping you join us, represent us in the United States." ${ }^{19}$ Han does not only aim at introducing "inside enemies" within the United States territory-a recurring element in the movies shot during the Cold War period-, he also epitomizes the "Yellow Peril," like Doctor Fu Manchu or Doctor No. ${ }^{20}$

21 In the trailer, it is already suggested that Han wishes to harm the United States and, even if he lives on an island, like the Chinese nationalists in Taiwan, he remains the villain, shaking up traditions in a pernicious way-as the spectator quickly learns that he has offended the Shaolin Temple. Against him, the American society as a whole stands up: Lee, of Asian origin, Roper, a WASP, and Williams, an African American, embody its diversity-hence the necessity to give them equal importance in the trailer. The American nation is portrayed as a united, even reconciled one, as Williams and Roper both fought in the Vietnam War.

While conveying such a message, the marketing of the movie can be associated to the "national interest" as defined by historian Arthur M. Schlesinger, Jr., "The moral content of national interest is determined by three things: by national traditions, by 
political leadership and by public opinion." ${ }^{21}$ In the trailer, the implicit goal of targeting a mass audience may be spotted and, in this sense, the context of the Cold War cannot be forgotten. For the Hong Kong audience, on the contrary, the character of Lee alone seems to dismantle Han's organization using his various skills and Enter the Dragon was protean enough to be to a different context, evidence of potential worldwide success. It is worth mentioning, once again, that the political dimension is by no means emphasized in the Hong Kong trailer, in which the various fight scenes checkering the movie only seem to count.

Going beyond the frame of this study, further questions could be raised: could this mean that the Asian audience was somewhat "infantilized," as it was deemed that mere fight scenes could be enough to attract spectators? Would this choice, on the contrary, reveal the wish to water down the political dimension-and the influence of the Cold War-to market the movie in various Far East countries? Both hypotheses deserve to be raised, but the eventual success of Enter the Dragon even shifted the balance from one part of the Pacific to the other, as the martial arts film then became more popular in the United States. The movie is even considered as a landmark in this process:

Eventually, the force and popularity of the kung-fu films themselves would lead to a genre we might call "martial arts", a genre that arose in the United States only after the kung fu crazed had passed. And it was Warner Brothers in the final analysis, that had preceded, initiated, and developed the craze, and helped shift the whole thing toward more American productions and orientation. ${ }^{22}$

It seems that Enter the Dragon could thus be used in a very "flexible" way, so as to attract wide audiences across the world and the various elements of the film were probably blended in this purpose. However, the success of a movie, more than the short-term benefits, can be measured by its influence and its perennial character. In those domains, the success of Enter the Dragon cannot be questioned: nowadays, the overall benefits amount to $\$ 90$ million dollars-for an initial cost of $\$ 850,000 .{ }^{23}$ It is generally ranked as one of the most outstanding films released in the year $1973^{24}$ and the marketing of the film continued throughout the years, giving rise to all sorts of products, even including figures representing Bruce Lee.

25 At the time, the work could have been interpreted as an abortive success: Lee died in mysterious circumstances on July 20,1973, a few weeks after the completion of the movie and a few days before its release, while Jim Kelly and John Saxon did not have other opportunities to come under the limelight. However, Enter the Dragon initiated a flurry of codes and references, so much so that subsequent movies were inspired by this blend of espionage, adventure and kung-fu, as the wish to benefit from the tremendous success of the movie emerged. Nowadays, its fame is rather accounted by the various fight scenes and the fact that the film was shot a short while before Lee's death, as proves the summary on the Rotten Tomatoes website:

One of the most popular king fu films ever, and perhaps the peak of the famed Bruce Lee's career, Enter the Dragon achieved success by presenting a series of superbly staged fighting sequences with a minimum of distractions. [...] Essential viewing for martial arts fans, the film was also embraced by a larger audience, thanks to a fast pace and higher-than-usual production values. ${ }^{25}$

26 Thus, it has to be underlined that the success of the film at the time was probably due to other elements, such as the blending between various other elements-especially the influence of the Bond franchise. On a larger perspective, a new continuity was initiated and it would even be possible to mention-as evidence of the links previously analyzed- 
The Shrine of Ultimate Bliss, a 1974 B-movie directed by Feng Huang, in which Bruce Lee was supposed to play the main character and dismantle a drug-trafficking ring. He was replaced by George Lazenby, the one-time James Bond in On Her Majesty's Secret Service (Peter R. Hunt, 1969), shot a few years earlier.

In this field, the movies did not automatically meet success and numerous films of average quality, now known as "Bruceploitation," followed, while the Bond franchise itself turned out to be influenced by Enter the Dragon-a form of poetic justice and a proof that "textual poaching" could now work in the reverse way. The following year, in The Man With the Golden Gun (Guy Hamilton, 1974), 007 once again travelled to the Far East, in Macao, Hong Kong, Thailand and Vietnam, and it even seemed necessary to include a scene in which he fought against martial arts champions. An extract was, of course, included in the trailer, another reference to Enter the Dragon and its worldwide fame. ${ }^{26}$ The way the film was successfully promoted in various areas of the globe undeniably contributed to it.

\section{BIBLIOGRAPHY}

Benoliel, Bernard. Opération Dragon, de Robert Clouse. Crisnée: Yellow Now, « Côté Films », 2010. Bordwell, David. Planet Hong Kong: Popular Cinema and the Art of Entertainment. Cambridge, MA: Harvard University Press, 2000.

Dars, Jacques. Au bord de l'eau. Paris: Gallimard, 1997.

Desser, David, and Fu, Poshek (eds.). The Cinema of Hong Kong: History, Arts, Identity. Cambridge: Cambridge University Press, 2002.

Fleming, Ian. Doctor No. London: Penguin, 2006.

Hergé. Les Cigares du pharaon. Bruxelles : Casterman, 1934.

Logan, Bax. Hong Kong Action Cinema. London: Titan Books, 1995.

Schlesinger, Arthur M., Jr.. The Cycles of American History. Boston-New York: Houghton-Mifflin, 1999.

Wyatt, Justin. High Concept: Movies and Marketing in Hollywood. Austen: University of Texas Press, 1994.

\section{Webography}

American and European trailer of Enter the Dragon:

http://www.youtube.com/watch?v=tB-QGOChuQc <accessed on September 10, 2012>

Hong Kong trailer of Enter the Dragon:

http://www.youtube.com/watch?v=Ksc_7StCIgU <accessed on September 10, 2012>

Lee's "crescent kick" in Enter the Dragon: 
http://www.youtube.com/watch?v=prqiKtmyVt4 <accessed on January 27, 2013>

Cost of Enter the Dragon and benefits brought in:

http://www.imdb.com/title/tt0070034/business <accessed on September 10, 2012>

Enter the Dragon in various rankings of the films released in the year 1973:

http://www.filmsite.org/1973.html <accessed on January 27, 2013>

http://www.films101.com/y1973r.htm <accessed on January 27, 2013>

The Rotten Tomatoes review of Enter the Dragon:

http://www.rottentomatoes.com/m/enter_the_dragon/ <accessed on January 26, 2013>

Trailer of The Man With the Golden Gun:

http://www.youtube.com/watch?v=Xzt6zAj7XUM <accessed on September 10, 2012>

\section{Films and television series cited}

Big Boss. Raymond Chow/Golden Harvest, Lo Wei, 1971.

Dirty Harry. Warner Bros., Don Siegel, 1971.

Enter the Dragon. Warner Bros./Raymond Chow, Robert Clouse, 1973.

Fist of Fury. Raymond Chow/Golden Harvest, Lo Wei, 1972.

Kung Fu. Jerry Thorpe, 1972-75.

The Lady from Shanghai. Columbia Pictures, Orson Welles, 1947.

Live and Let Die. United Artists, Guy Hamilton, 1973.

The Man With the Golden Gun. United Artists, Guy Hamilton, 1974.

Mission: Impossible. Desilu Productions/Paramount Television, 1966-73.

On Her Majesty's Secret Service. United Artists, Peter Hunt, 1969.

Return of the Dragon. Raymond Chow/Golden Harvest, Bruce Lee, 1972.

Shaft. MGM, Gordon Parks, 1971.

The Shrine of Ultimate Bliss. Raymond Chow/Golden Harvest, Huang Feng, 1974.

Thunderball. United Artists, Terence Young, 1965.

Vera Cruz. MGM, Robert Aldrich, 1954.

You Only Live Twice. United Artists, Lewis Gilbert, 1967.

\section{NOTES}

1. Justin Wyatt, High Concept: Movies and Marketing in Hollywood (Austin: University of Texas Press, 2006), 12-13.

2. Jacques Dars, introduction to Water Margin (Paris : Gallimard, 1997), 8.

3. David Desser and Poshek Fu (eds.), The Cinema of Hong Kong: History, Arts, Identity (Cambridge: Cambridge University Press, 2002).

4. Enter the Dragon (Robert Clouse, 1973). 
5. Shaft (Gordon Parks, 1971) is often considered as a pioneer movie in this trend.

6. "Baroque" may, in this case, be defined as opposed to classicism and giving free course to imagination.

7. Enter the Dragon was released in Hong Kong on July 26, 1973, and in the United States on August 19, while Live and Let Die was released in the United States on June 27 and in Great Britain on July

12.

8. Bernard Benoliel, Opération Dragon, de Robert Clouse (Crisnée : Yellow Now, "Côté Films », 2010)

8.

9. Enter the Dragon (Robert Clouse, 1973).

10. Bey Logan, Hong Kong Action Cinema (London: Titan Books, 1995), 111.

11. http://www.youtube.com/watch?v=tB-QGOChuQc <accessed September 10, 2012>.

12. See http://impawards.com/1973/enter_the_dragon.html <accessed March 8, 2013>.

13. See http://www.filmposter.net/movieposters/poster/movie/original/enter-the-dragon-8 $<$ accessed March 8, 2013>.

14. Internet link: http://www.youtube.com/watch?v=Ksc_7StCIgU <accessed September 10, 2012>.

15. Source: http://www.youtube.com/watch?v=prqiKtmyVt4 <accessed January 27, 2013>.

16. David Bordwell's study Planet Hong Kong: Popular Cinema and the Art of Entertainment (Cambridge, MA: Harvard University Press, 2000) has to be mentioned here.

17. This idea was initially developed by Michel de Certeau in his work L'invention du quotidien (Paris: Gallimard, 1980).

18. Pay attention to the order in which the characters are respectively mentioned: the one played by Bruce Lee once again comes last.

19. Enter the Dragon (Robert Clouse, 1973).

20. In the novel by Ian Fleming, published in 1958, it is clearly stated that Doctor No works for Chinese Communists-contrary to the film, shot four years later, in which he works for the terrorist organization SPECTRE.

21. Arthur M. Schlesinger, Jr., The Cycles of American History (Boston-New York: Houghton-Mifflin, 1999), 80.

22. Desser and Fu (eds.), The Cinema of Hong Kong, 26-27.

23. Source: http://www.imdb.com/title/tt0070034/business <accessed September 10, 2012>.

24. Sources: http://www.filmsite.org/1973.html <accessed January 27 2013>, http:// www.films101.com/y1973r.htm <accessed on January 27, 2013>.

25. http://www.rottentomatoes.com/m/enter_the_dragon/ <accessed January 26, 2013>.

26. http://www.youtube.com/watch?v=Xzt6zAj7XUM <accessed September 10, 2012>.

\section{ABSTRACTS}

Enter the Dragon, released in 1973, was the first ever film co-produced by a Hollywood studio and a Hong Kong production company. It was intended to launch the career of actor and martial arts champion Bruce Lee in the United States and, in this way, its promotion included elements that, on the one hand, reminded one of the previous films that had made him famous, but, at the same time, could also be associated to contemporary popular movies-in particular, those of the James Bond franchise. In this article, the marketing of Enter the Dragon is analyzed particularly through 
the study of various posters and trailers, which were different according to the countries or areas in which it was released. Borrowing from other works, Enter the Dragon was at the crossroads of various genres, but contributed to initiate other codes in adventure or action movies, which have been used ever since.

INDEX

Keywords: movies, marketing, popular culture, representation, codes

\section{AUTHOR}

PIERRE-FRANÇOIS PEIRANO

Pierre-François Peirano is an Assistant Professor in English and American Studies at the Université du Sud Toulon-Var. His PhD, to be published within the next few months, was devoted to the representations inspired by the Lewis and Clark Expedition and his research interests include domains such as the cinema industry, iconography, painting and popular culture. 